\title{
Jesus and Mehr recognition according to oriental sources
}

\begin{tabular}{|c|c|}
\hline \multicolumn{2}{|c|}{$\begin{array}{l}\text { Authors: } \\
\text { Amir A. Rokhzadi }{ }^{1,2} \\
\text { Kaivan Shafei }^{1,2}\end{array}$} \\
\hline \multicolumn{2}{|c|}{$\begin{array}{l}\text { Affiliations: } \\
{ }^{1} \text { Department of History, } \\
\text { Faculty of Humanities, } \\
\text { Sanandaj Branch, Islamic Azad } \\
\text { University, Sanandaj, Iran }\end{array}$} \\
\hline \multicolumn{2}{|c|}{$\begin{array}{l}{ }^{2} \text { Department of Science of } \\
\text { Religion and Missiology, } \\
\text { Faculty of Theology and } \\
\text { Religion, University of } \\
\text { Pretoria, South Africa }\end{array}$} \\
\hline \multicolumn{2}{|c|}{$\begin{array}{l}\text { Research Project } \\
\text { Registration: } \\
\text { Project Leader: J. Beyers } \\
\text { Project Number: } 02440237\end{array}$} \\
\hline \multicolumn{2}{|c|}{$\begin{array}{l}\text { Description: } \\
\text { This research is part of the } \\
\text { project, 'Religion, Theology } \\
\text { and Education', directed by } \\
\text { Prof. Dr Jaco Beyers, } \\
\text { Programme Manager: Biblical } \\
\text { and Religious Studies and } \\
\text { member of the Department } \\
\text { of Science of Religion and } \\
\text { Missiology, Faculty of } \\
\text { Theology, University of } \\
\text { Pretoria. }\end{array}$} \\
\hline \multicolumn{2}{|c|}{$\begin{array}{l}\text { Corresponding author: } \\
\text { Kaivan Shafei, } \\
\text { kaivan_shafei@yahoo.com }\end{array}$} \\
\hline \multicolumn{2}{|c|}{$\begin{array}{l}\text { Dates: } \\
\text { Received: } 29 \text { Sept. } 2017 \\
\text { Accepted: } 20 \text { Jan. } 2018 \\
\text { Published: } 22 \text { Mar. } 2018\end{array}$} \\
\hline \multicolumn{2}{|c|}{$\begin{array}{l}\text { How to cite this article: } \\
\text { Rokhzadi, A.A. \& Shafei, K., } \\
\text { 2018, 'Jesus and Mehr } \\
\text { recognition according to } \\
\text { oriental sources', HTS } \\
\text { Teologiese Studies/ } \\
\text { Theological Studies 74(1), } \\
\text { 4825. https://doi. } \\
\text { org/10.4102/hts.v74i1.4825 }\end{array}$} \\
\hline \multicolumn{2}{|l|}{ Read online: } \\
\hline 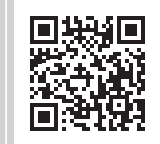 & $\begin{array}{l}\text { Scan this QR } \\
\text { code with your } \\
\text { smart phone or } \\
\text { mobile device } \\
\text { to read online. }\end{array}$ \\
\hline
\end{tabular}

Early oriental historians have used two series of sources about ancient history of Iran, including Iranian and non-Iranian sources. As these sources are independent of each other, two different chronologies about these ancient periods have arisen. Naturally, this duality has led to different and contradictory results about dating important events of this period. One of them is the contradictory reports about two separate religious personalities - Messiah Mehr and Jesus of Nazareth. Despite the fact that these historians have taken the identity and time of appearance of Messiah Mehr and Jesus from the abovementioned two sources, they unknowingly considered the two characters as one and the same person. Al-Mas'udi is one of the earlier oriental historians who made remarkable reports and points regarding the alterations of political and religious history of the Ashkanian dynasty by the earlier Sasanians. These alterations caused the reality of Messiah Mehr to be concealed. This article tries to explain briefly the reasons for this topic through the viewpoints of oriental historians with emphasis on Al-Mas'udi's reports.

\section{Introduction}

One of the difficulties about studying ancient Iran is related to the Ashkanian ${ }^{1}$ Empire and the beginning of the Sasanian ${ }^{2}$ Empire. The most important aspect of this problem relates to religion and the history of religions in the Ashkanian period. In this article, we will show that owing to the reports of the eastern historians, especially Al-Mas'udi's (died 956) narrations, two saviours, namely, Mehr (or Messiah Mehr) and Jesus of Nazareth (or Jesus Christ) have appeared.

There is a concept of Messianism or belief in a saviour in almost all ancient religions, and 'Saviour' is a generic term that means a saver or a liberator of people. For example, in the Old Testament texts, this person is called Christ. The writers of the four Gospels and the early Christians considered Jesus of Nazareth as the saviour, as promised by the Torah, while the Jews do not have such a belief; in the Zoroastrian faith, the ultimate saviour is called Saoshyant. In the narrations of the early Islamic historians, both the Messiah and Jesus of Nazareth have been mentioned, but because of using two independent sources, both Persian and Western, they hinted at the appearance of two distinct characters, one called the Mehr or Mehr Messiah who appeared in the Parthian territory, and the other was Jesus of Nazareth. But they unknowingly considered the two personalities as one and the same character.

Historical evidence suggests that the cult of Mehr was common during the rule of the Ashkanian Empire and that in Europe Mithraism was the official religion in the early 4th century. Mithraism came to an end with the emergence of the Sasanians in 224 AD but continued in Europe until a century later. Is it possible for such a religion to be without a founder? The logical answer is in the negative. Therefore, a critical question is 'why are there no explicit mentions of Mehr in historical texts?' The author believes that there are distinct reasons for the wiping off of the works of Mehr and Mithraism in Iran and Europe. As far as Iran is concerned, Al-Mas'udi has a remarkable reference to this issue, that is, the distortion of the political and religious history of Ashkanians by the early Sasanians; this resulted in the elimination of the theme of the advent of a saviour from the history of the Ashkanian era. But unfortunately he did not present the mentioned distortion in his report on the major events of the Ashkanian era, including the advent of a saviour. In Europe, Mithraism declined because of hostilities and the long wars of the Romans with the Ashkanians and because of the acceptance of Christianity by the emperor Constantine the Great. More importantly, all the works and beliefs of Mithraism were attributed to the new religion of

1.The Ashkanian or Parthian Empire was the third dynasty of ancient Iran (250 BC - 224 AD)

2.Sasanian Empire was the last dynasty of ancient Iran (224 BC - 652 AD). The Sasanians set aside the political federalism of the Parthians and their religious tolerance, as well as bringing religion into politics, and created a centralised state system. 
Jesus, which had a non-Iranian nature. Thus, Europeans were absolutely able to assign the word of Christ to Jesus of Nazareth. The result was that Mithraism was invaded by both the Sasanians and the Europeans. It was a campaign which resulted in the stabilisation of the Zoroastrian faith in Iran and the religion of Jesus in the west. It was the root of a historical distortion that has continued so far.

But the historical status of Jesus of Nazareth as a saviour is also not clear according to the famous historians of the 1st century AD. The works of historians such as Philo of Alexandria (20 BC - 50 AD), Flavius Josephus (37 AD - 100 AD), Suetonius (69 AD - 130 AD) and Plutarch (46 AD - 126 AD) are notable in this regard. There is no mention of Jesus Christ by Plutarch but Josephus has mentioned Jesus in his work The Antiquities of the Jews (Josephus 2006:1046). According to many scholars, this text was forged by Christian scribes to show that Josephus believed in the divinity of Jesus, while that was not really the case. This description has been so awkwardly forged that most scholars have recognised it as fake (Ashtyani 1989:173). In the late 19th century, the renowned physician and Christian scholar 'Albert Schweitzer' officially declared the falsity of this description and even the church could not deny it in the 20th century (ibid). In the book of The Lives of the Twelve Caesars, in chapter 5 (about Claudius), Suetonius (1979) has a brief description of Chrestus:

He (Claudius) banished from Rome all the Jews, who were continually making disturbances at the instigation of one Chrestus. (p. 202)

Maybe he meant Chrestus was Jesus. But he did not know this person to the extent that he thought he was still alive at the time of Claudius. This unknowingness makes his report about Jesus questionable. The term Chrestus, which means a saviour, was common among Romans, especially among slaves. The English historian 'Gibbon' also points to the rebellion and emphasises that the rebels were Jews who had risen up in the hope of their old beliefs about the advent of the victorious Christ to free themselves from captivity (Ashtyani 1989:177). The duality of resources used by the early Islamic historians, especially Al-Mas'udi, has led to two different chronologies - the chronology of Iranian reports denotes Messiah Mehr, while the chronology of non-Iranian reports denotes Jesus Christ.

Of course, the idea of two saviours at two distinct times is considered by some of the contemporary researchers that will be noted briefly here. But this article tries to inspect this subject based on Al-Mas'udi's texts and present the historical reasons for the difference between Messiah Mehr and Jesus. Before that, it is necessary to introduce a summary of the most important reports of other early Islamic historians about this topic.

\section{Oriental historians' report}

Abu-Hanifa Ahmad ibn Dinawari (died 896 AD) in al-Akhbār al-Tiwal said that Alexander founded the Ashkanian Empire (Dinawari 1967:64) and gave the government of the
Jabal to Ardavan. Dinawari said that Jesus the son of Maryam was appointed as prophet at the time of Ardavan (ibid 66). He also said that Jesus' appearance was at the time of Ardashir-e-Papakan, progenitor of the Sasanian dynasty (ibid 71). Tabari (died 921 AD) had a different opinion about the birth of Maryam's son (Jesus) in Tarikh al-Tabari. He said Jesus was born 51 years after the beginning of Molouk-al-tavayef (Ashkanian) and reported that the age of Ashkanian from Alexander to the rising of Ardashir the son of Pāpak and to the killing of Ardavān was 266 years (Tabari 1996:v2, 499). One of the points of interest to Islamic historians, such as Tabari, is the alternate destructions and reconstructions of Jerusalem. Tabari had two narratives about this subject. He believed that the first one is a Jewish and Christian view and the other an Iranian opinion. There is a difference of 252 years between these two narratives, with respect to the period between the first desolation of Jerusalem and the birth of Yahya (John) (ibid 507). However, in his speech, there is no difference between the abovementioned two narratives regarding the period between the first desolation of Jerusalem until the time Alexander the Great conquered Babylon, but the difference is related to the period from the time Alexander the Great conquered Babylon until Jesus' birth (ibid). Miskawayh (died 1030 AD) in his book Tajarib-al-Umam wrote that Jesus was born in Palestine and appeared at the time of Sābour (Shāour), the second king of the Ashkanian dynasty (Miskawayh 1987:44). Sa'ālebi (died 1036 AD) also in his book said that Jesus was a contemporary of the second king of Ashkani (Sa'ālebi 1989:288). Ibn al-Athir (died 1232 AD) in al-Kamel fi Tarikh said that Jesus appeared at the 41st year of the second Ashkani king's rule (Ibn al-Athir 2004:344). He pointed to the differences in the duration of the Ashkanian dynasty and said that some historians consider that time to be 260 years, some others as 344 years and still others as 523 years (ibid 345). He said that the killing of John was at the time of Ardashir Pāpakān and 1.5 years before the ascension of Jesus according to the opinion of some researchers (ibid 356). About the time of Jesus' birth, he said that Iranians believe that this event happened 55 years after Alexander dominated Babylon and 51 years after the foundation of the Ashkanian dynasty and that Christians believe that Jesus was born 363 years after Alexander dominated Babylon (ibid 357-358). About the beginning of the Ardashir Bābakān governance, Ibn al-Athir said that Ardashir Bābakān rose to power 523 years after Alexander's conquest of Babylon, by Jewish and Christian narratives, and 266 years after the said conquest by the Iranians' narrative (ibid 441). Ibn Khaldun's (died 1404 or 1406 AD) narrative about these subjects is similar to that of Tabari and Al-Mas'udi, without any new points (Ibn Khaldun 2004:v 1, 153-185).

As can be seen, for some reasons, these historians were uninformed about the details of history between the time of Alexander and Sasanian. This problem led to contradictory narratives, especially about the idea of the appearance of the saviour. This fact can be an indication of the agitation and disturbance with regard to the Ashkanian history. Al-Mas'udi's narrative addresses these ambiguities. 


\section{Al-Mas'udi's report}

Al-Mas'udi in his book al-Tanbih wal Ishraf accounts for Ashkanian as the fourth class of the ancient kings of Iran (Al-Mas'udi 2010:89). Similar to other Islamic historians, Al-Mas'udi mentioned one chain of Ashkanian, including 11 kings with a total reign of 268 years (ibid 90). But he said that the reign of the Ashkanian dynasty after the killing of Dāryush III until the rising of Ardashir bābakān was 513 years, because the period between the first year of Alexander's reign, till 956 AD (345 A.H.) $)^{3}$, is 1267 years. If we subtract the values of 313 years (killing of Yazdgerd III in 32 A.H. till 345 A.H. = 313 years) and 437 years (reign of the Sasanian empire per Al-Mas'udi's belief) from 1267, we can derive the value of 517 years. It is the duration from the killing of Dāryush III by Alexander till Ardashir's rising. AlMas'udi believed that this value denoted the reign of the Ashkanian Empire (ibid 90). Al-Mas'udi's calculation is: $1267-(437+345-32)=517$ years, which is 4 years more than 513. Probably this difference has resulted in the confusion between Shamsi and Qamari calendars. ${ }^{4}$ We are not sure whether he changed the Qamari years to Shamsi in his calculations or not. If all of the numbers from Alexander to the Al-Mas'udi's age and Sasanian period are in Shamsi scale, only 345 and 32 would be in the Qamari scale. The year of 345 Qamari is equal to 335 Shamsi, and 32 Qamari is equal to 31 Shamsi. Therefore, by replacing these years in the above equation, the result will be 525 years, which is again different from that calculated by Al-Mas'udi.

Of course, there are a few other points. Was the real duration of Sasanian and the time from the accession of Alexander till Al-Mas'udi's age the same as what Al-Mas'udi said? He noted that the beginning of the Ashkanian is from the killing of Dāryush III, but his calculations are based on Alexander's accession, and none of them represent the real beginning of the Ashkanian. Based on the present information, we know that Ardashir Pāpakān rose to power in $212 \mathrm{AD}$ and he defeated Ardavān V in 226 AD (Bayāni 2013:29), and usually this year has been accounted as the beginning of the Sasanian. The killing of Yazdgerd III happened in 652 AD (Pirnyā 2013:233), which means 31 Qamari or 30 Shamsi. Thus, the total reign of the Sasanian was 426 solar years or 439 lunar years. Probably, Al-Mas'udi would have calculated the Sasanian period based on lunar years, resulting in a difference of 13 years. There can be some doubt regarding the duration of Alexander's accession till Al-Mas'udi era. Philip died in 336 BC and he was succeeded by his son at that time (ibid 106). Al-Tanbih wal Ishraf was compiled in 345 Qamari, which equals to 956 AD. So the period between Alexander's accession and compilation of this book equals to 1292 years, that is, 25 years more than the number mentioned by Al-Mas'udi. However, it is improbable that this difference resulted from confusion between the Qamari and Shamsi scales, because the number noted by Al-Mas'udi is less. Now the calculations are repeated again:

\section{Anno Hegirae (After Hijrah)}

4. Hijri Qamari and Hijri Shamsi are Islamic calendars consisting of 12 months. Hijr Qamari is a lunar calendar with 354 (or 355) days and Hijri Shamsi is a solar calenda with 365 (or 366) days.
The value of 560 years $(=1292-[426+336-30])$ is in solar scale and more than Al-Mas'udi's numbers. But this value is from Alexander's accession till Ardashir's reign, and includes Alexander and his Greek successors (Seleucids) and Ashkanian. Alexander died in 323 BC in Bābylon and Seleucids ruled over Iran and Mesopotamia until 250 BC. By subtracting the years of reign of Alexander (13 years) and Seleucids in mainland Iran (73 years) from 560, we derive the value of 474 , which is approximately equal to 476 years of Ashkanian's domination. The difference of 2 years is because of the conversion of Qamari years to Shamsi years. In general, with regard to calculations, Al-Mas'udi adopted the correct method in his report. But this is not the focus of the topic. More importantly, he pointed to an important tip that the most proficient of historians such as Tabari and Ibn Khaldun did not mention. His report in this respect is:

I explained totally about this subject in Muruj adh-dhahab book. That is the latest version after many editions and this text is several times more than the primary edition of 333 A.H. I told this matter because the old edition was distributed among many people. Iranians have an important difference with others about Alexander's history, and many people are unaware of it. Because as I have seen in Fars, Kerman and other states of Iran, it is a royal and religious secret, and nearly nobody knows it, with the exception of Moubadān and Hirbadān (Zoroastrian clergies) and scientists. More over there is no mention of it, in any of the books about Iranians and their history. The subject is that the Zoroaster said in Avesta, after 300 years their country will be agitated and their religion will remain. But after 1000 years, both country and religion together will have disappeared. There is near 300 years between Zoroaster and Alexander time and Ardashir Papakān got the reign 510 and a few years after Alexander and noticed that 200 years is remaining to the end of the mentioned 1000 years. So he wants to extend the kingdom, because he feared after the 200 years, people may not support Sasanian reign. So he reduced the half time between Alexander and himself. Then he said that the duration of Alexander time to the killing of Ardavān had been 260 years. Thus, this history was common among people. Accordingly difference between Iranians and other nations was arisen and consequently the history of Ashkānian was agitated. (Al-Mas'udi 2010:90-92)

Also, he narrated the parts of Tansar's letter on the same subject (ibid 92-93). Pirnyā believes that it is difficult to comment on the rightness or wrongness of Al-Mas'udi's report, because it is not mentioned in Avesta (Pirnyv 2002:v3, 2452). Of course, Pirnyā's doubt is not acceptable, because if it were a royal and religious secret, it cannot be pointed out and revealed in a religious text. However, Pirnyā takes one step forward and says that there is a historical explanation in support of Al-Mas'udi's claim, that is, historians for compensating for the deduction of Ashkanian's duration by Ardashir, added nearly the same time period to the duration between Goshtāsp and Key-Ghobād (ibid 2452). Of course, he has considered Kyāniān equal to Achaemenian, following the tradition. As Pirnyā says, the aim was to reduce the millennium gospel, so the years which were deleted by Ardashir, were added to the time period before Zoroaster, because by adding to the time period after Zoroaster, they would not achieve their goals. Of course, nowadays, the 
traditional narration about the time of Zoroaster is rejected (Amoozgār \& Tafazzoli 1991:v1, 13-16), but the important subject was the political and ideological exploitations of this issue by Sasanians.

Al-Mas'udi's report answers two ambiguities. One of them is regarding why most Islamic historians made a mistake in the calculation of Ashkanian's duration and the names of Ashkanian kings. The reason is that early Zoroastrian governors of Sasanian and the first of them, Ardashir Pāpakān, as a result of religious belief and for postponing a religious prediction deleted the half period of Ashkanian. Results of this subject are reflected in the series of Iranian sources. Second of them is that the time of Ardashir's accession will be nearly a quarter of a millennium earlier and contemporary with the birth of Jesus of Nazareth. So the opinion of some of the Islamic historians such as Dinawari and Ibn al-Athir regarding the advent of Jesus in the era of Ardashir can be justified. But an important problem still remains, that is, two historical narrations regarding the time of the saviour's birth, which is explained as follows.

\section{Jesus and Mehr}

There are two narratives in this respect; the Iranian and the Christian narrations. Unfortunately, none of the mentioned authors answered this question: 'why do these narrations have as many differences as much as centuries?' The fact is that there are two different chronologies. The Iranian narration implies the birth of a saviour based on Ashkanian chronology, while on the other hand the Christian narration implies the birth of Jesus based on the chronology of Greek and Roman kings after Alexander the Great. Here is a review of both narrations according to Al-Mas'udi's report:

1. Based on the Ashkanian chronology: He says the Messiah appeared in the 41st year of the second Ashkanian king, namely, Shapour (Al-Mas'udi 2005:v1, 179). This subject has also been mentioned in the famous book of AlMas'udi named al-Tanbih wal Ishraf as well as noted by other historians. So the birth of the Messiah is $20+41=61$ years after Alexander. This number, according to Tabari, is 51 years (Tabari 1996:v2, 499).

2. Based on Greek and Roman kings' chronology: AlMas'udi said that the time between Alexander's kingdom until Jesus' birth is 369 or 309 years (based on a narration that he saw in Ghasban's church at Antakiyeh) (AlMas'udi 2005:v1, 233); however, it is not clear what he meant by Alexander's kingdom - the beginning or the end of Alexander's kingdom or mastery on Babylon? Moreover, he has presented various other numbers, summarised as follows:

- From the beginning of Alexander's reign until Cleopatra's death, there were 291 years and 18 days (Al-Mas'udi 2010:104-106), and from Cleopatra's death until Jesus' birth, there were 30 years (ibid 115); then, by subtracting the duration of the kingdom of Alexander (13 years), the time between Alexander's death and Jesus' birth will be 308 years.
- From Alexander's death until Cleopatra's death, there were 301 years (Al-Mas'udi 2005:231), and from Cleopatra's death until Jesus' birth, there were 30 years; so, the time from Alexander's death until Jesus' birth is 331 years.

Assuming that the rule of Alexander lasted 13 years, the upper and the lower limits of duration between Alexander's death and Jesus' birth based on the mentioned quotations are 356 and 296 years, respectively. We know that Alexander died in Babylon in 323 BC (Pirnyā 2002:v2, 1869, 2013:142).

Therefore, different numbers for the birth date of the 'Saviour' can be mentioned as follows:

1. Based on the Ashkanian chronology, the year of 262 BC from Al-Mas'udi (I) and the year of 272 BC from Tabari (II) are obtained.

2. Based on the Greek and Roman chronology, a range of numbers including the years of 27 and $16 \mathrm{BC}$ and the years of 8 and $33 \mathrm{AD}$ are obtained, here marked as III, IV, $\mathrm{V}$ and VI, respectively.

It is clear that the numbers of $27 \mathrm{BC}, 16 \mathrm{BC}, 8 \mathrm{AD}$ and $33 \mathrm{AD}$ are related to the birth of one person and the differences between them are likely referred to opinion differences between various factions of Christianity or have arisen from mistakes done by copiers of old sources or from mistakes of verbal narrators being increased over time. On the contrary, the numbers of 262 and 272 BC are obviously related to the birth of another person because their differences with four other numbers are so great that it can't be done inadvertently. Accordingly, the concurrency of the birth date of these two personalities cannot be easily accepted, especially since the numbers of 262 and 272 BC have resulted from sources based on Iranian beliefs and traditions that are independent of Christian, Greek and Roman narrations.

In fact, Al-Mas'udi and other early Islamic historians (Dinawari, Tabari, Miskawayh, Sa'ālebi, Ibn al-Athir and Ibn Khaldun) have noted two different personalities by using two chains of independent sources without knowing this issue.

The first character was a prophet who appeared at the time of the early part of the Ashkanian Empire or the middle of the 3rd century BC. The second character known as Jesus of Nazareth was born late during the reign of Herod the Great in Palestine.

Al-Mas'udi in Muruj adh-dhahab says about a person according to Ashkanian's chronology as follows: The first king of the Ashkanian was Ashk the son of Ashk who reigned for 20 years. After him, Sabour (Ashk's son) reigned for 60 years, and in the 41st year of his kingdom, Sir Almessiah appeared in Iliya, Palestine (Al-Mas'udi 2005:v1, 179). Furthermore, about the birth of a person according to Greek 
and Roman chronology, he says: 'The time of Jesus' birth is in the 42nd year of Augustus kingdom' (ibid 233).

Al-Mas'udi has made a mistake in applying the titles of 'Ashkanian Messiah' and 'Jesus of Nazareth' because he has mixed the Iranian and non-Iranian narrations. He made similar mistakes regarding the birth place of 'Ashkanian Messiah' that he named 'Messiah (Peace Be Upon him)' because this Messiah was not born in 'Iliya'5 and the name of Illya was given to Jerusalem in the 2nd century (Behrouz 2008:122).

Behrouz (2008) in his book called Calendar and history in Iran said that: Two Messiahs appeared in two separate times, and one of them has not been crucified (ibid 121), then he quoted this phrase from 'The Second Letter of St. Paul to the Corinthians':

For if he that cometh preacheth another Jesus, whom we have not preached, or if ye receive another spirit, which ye have not received, or another gospel, which ye have not accepted, ye might well bear with him. (Jesus Bible, 2 Cor 11:4; Bible 1978)

It is obvious that in the era when St. Paul pointed out this subject to the Corinthians, the existence of another Messiah has been accepted as a fact. Otherwise there was no need for St. Paul to restrain Christians from following that person. A statement from Ya'qubi (died 892 or 898 AD) says that: 'I believed that the matters related to Ashkanian era are inappropriate so I refrain from mentioning them' (Ya'qubi 2003:v1, 194). Is it possible that the retelling of the facts of the Ashkanian era interfere with the commonly accepted beliefs regarding Jesus of Nazareth? Of course, it may be said that St. Paul's purpose was two interpretations of one person, that is, Jesus Christ. But for two reasons, St. Paul's emphasis is not on two interpretations of a character, but on a challenge of two characters. Firstly, the interpretative trends concerning the nature and personality of Jesus emerged in the 4th century $\mathrm{AD}$ which arose from the interpretation of 'Arius' and 'the Council of Nicaea'. Secondly, St. Paul, who sought to spread Christianity beyond the borders of Palestine, feared that the Christianity which he founded would be affected and wiped out by Mithraism in the territories of the Roman Empire.

The first person is named Mehr, MiӨra, Mishā, Misā, Mashihā, Masihər and Messiah, all of which are derived from one and the same origin (Yektāey 1970:92). Messiah is a prophet who is also called 'Saoshyant Mehr' (ibid 94). This Messiah is the same saviour who was born at the beginning of the Ashkanian era. A summary of annotations in Turfanic calendars from the article of 'Mithraism and Saoshyant Mehr' is mentioned here: in the 51st year of Ashkanian reign, on Friday the 5th day of spring, from God the good news of pregnancy was given to Mehr's mother and after 275 days, on Saturday night 25 December (272 years before the Jesus birth), Mehr was born (ibid 95). Note that this date is the same number of $272 \mathrm{BC}$ that was pointed to as number II previously in the current paper.

5.lliya is one of the ancient names of Jerusalem

\section{Conclusion}

The reports of Al-Mas'udi and other early Islamic historians about Ashkanian contain defects and ambiguities. These historians used two series of independent sources, including Iranian and non-Iranian ones. Applying two different sources in this respect has caused confusion about the date of the advent of two saviours in two different centuries. The alterations of Ashkanian history by Sasanians, especially Ardashir, resulted in turmoil in Iranian sources. These manipulations have arisen from Sasanians' rancour against Ashkanian and their lack of willingness to accept a millennium based on Iranian religious beliefs as the millennium of the saviour's appearance. Regardless of the validity of this idea, what matters from a historical viewpoint are the associated reactions on this issue. Removing a quarter of a millennium of Ashkanian history led to chaos and disorder in calculations and reviews such as mixing the personality of two separate characters of Messiah Mehr and Naserian Jesus. Of course, the omission of the name of Messiah Mehr has been desirable to the Sasanian because the advent of a saviour in the Ashkanian era was not pleasant for Sasanians from an ideological point of view.

It can be concluded from Al-Mas'udi reports that there have been two saviours. One of them called 'Messiah Mehr' at the beginning of the Ashkanian era and the other called 'Naserian Jesus' in Palestine. Iranian narrations imply to the first character and non-Iranian narrations imply to the second character. According to the writings and notes of Islamic historians, it becomes clear that they took into account the two personalities as one character.

\section{Acknowledgements Competing interests}

The authors declare that they have no financial or personal relationships which may have inappropriately influenced them in writing this article.

\section{Authors' contributions}

The research was carried out by A.A.R and K.S is the corresponding author.

\section{References}

Al-Mas'udi, A.A., 2005, Muruj adh-dhahab, vol. 1, Al'asriyah Publication, Beyrout.

Al-Mas'udi, A.A., 2010, al-Tanbih wal-Ishraf, transl. A. Pāyandeh, Elmi \& Farhangi Publication, Tehran.

Amoozgār, J. \& Tafazzoli, A., 1991, Myth of Zoroaster's life, vol. 1, Ketābsarāyebābol Publication, Babol.

Ashtyani, J., 1989, Research about the Messiah Religion, Negāresh Publication, Tehran.

Bayāni, S., 2013, Ashkanian's setting \& Sasanian's rising, Tehran University Publication, Tehran.

Behrouz, Z., 2008, Calendar \& history in Iran, Cheshmeh Publication, Tehran.

Bible (Commentary Translate), 1978, Commentary translate of the Holy Bible Organization, Tehran.

Dinawari, A.A., 1967, al-Akhbār al-Tiwal, transl. S. Neshat, Iranian's Culture Institution, Tehran.

Ibn al-Athir, A., 2004, al-Kāmel fi Tārikh, vol. 1, transl. S.M.H. Rouhani, Asatir Publication, Tehran. 
Ibn Khaldun, A.Z.A., 2004, al-Ibar, vol. 1, transl. A.M. Ayati, Human Science \& Cultural Studies Institute, Tehran.

Josephus, F., 2006, The antiquities of the Jews, viewed 4 February 2018, from http:// www.documentacatholicaomnia.eu/03d/0037-0103,_Flavius_Josephus,_The Antiquities_Of_The_Jews,_EN.pdf

Miskawayh, A.A., 1987, Tajārib-al-Umam, A. Emami (ed.), Soroush Publication, Tehran.

Pirnyā, H., 2002, Ancient Iran, vol. 2, Zarrin \& Negarestan Publication, Tehran.

Pirnyā, H., 2013, Ancient Iran from the beginning till Sasanian's overthrow, Dabir Publication, Tehran.
Sa'ālebi, A., 1989, Sa'ālebi's History, transl. M. Fazā’eli, Noghreh Publication, Tehran. Suetonius, 1979, Lives of the twelve Caesars, transl. R. Graves, rev. Michael Grant, Penguin, New York.

Tabari, M., 1996, Tarikh al-Tabari, vol. 2, transl. A. Pāyandeh, Asatir Publication, Tehran.

Ya'qubi, A., 2003, Tarikh al-Ya'qubi, transl. M.E. Āyati, Elmi\&Farhangi Publication, Tehran.

Yektāey, M., 1970, 'Mithraism \& Saoshyant Mehr', Historical Researches Magazine, 5th Year 6, 91-98. 